\title{
Crusader Heritages and Imperial Preservation ${ }^{1}$
}

\author{
Astrid Swenson
}

\section{Re-entangling histories}

Visitors keen to see French heritage in a nutshell need not strive far from the Eiffel Tower. At the Museum of French Monuments, reopened in 2007 as part of the National City of Architecture and Heritage, one can experience the history of French architecture, sculpture and wall painting in three dimensions. A 'point of reference for all audiences, permitting to understand the historic roots of the most contemporary aims in architectural creation and urban policies', the museum's own development is less visible. ${ }^{2}$ Founded in 1879 as a cast collection for the training of architects and the education of the public, the displays always consisted of models and copies. In contrast to originals, these copies could be ordered to demand, allowing the curators to create an ideal museum, easily adaptable to changing understandings of heritage. Its history is therefore a microcosm for observing broader transformations in the heritage canon. For a long time, this canon was not limited to the art of the Hexagon. The institution was in fact founded as the Museum of Comparative Sculpture, juxtaposing French Medieval to Ancient and foreign works of art. It was only in the 1930s that it was rebranded as the Museum of French Monuments. Yet despite the new title, the display was not confined to works originating in metropolitan France, but rather explicitly included material that demonstrated the spread of French influence beyond national borders. A particular highlight was a new room on the art of the Crusades. Filled with casts from the Levant, at its centre stood a model of what T.E. Lawrence called 'perhaps the best preserved and most wholly admirable castle in the world', the Crac des Chevaliers in Syria. ${ }^{3}$ France had acquired the Crac in 1934 and restored it extensively. A publicity campaign through the Colonial Exhibition in 1931, the Museum of French Monuments and the Museum of the Colonies at Vincennes accompanied the restoration

\footnotetext{
1 I am grateful to Paul Betts, Corey Ross, Rana Mitter and the participants of the 'Heritage in the Modern World' conference, as well as to Peter Mandler, Simon Goldhill, Richard Evans, David Motadel, Tamson Pietsch, Alison Carrol, Tamara van Kessel, Krishan Kumar and Samuel Aylett as well as to the anonymous readers for their comments on the paper, and to the Leverhulme Trust and the British Academy for supporting the research.

2 Ministère de la Culture et de la Communication, Cité de l'Architecture et du Patrimoine,

http://www.citechaillot.fr/fr/cite/trois departements/departement patrimoine/, accessed 25 Feb. 2013.

3 T.E. Lawrence, Crusader Castles (London, 1936); Paul Deschamps, 'Project d'amenagement du Musée des monuments français', 5 Apr. 1935, Archives des Musées nationaux, Paris (hereafter AMN), U1 Trocadéro. In the sources of the period both 'Crac' and 'Krak des Chevaliers' were used to refer to the fortress known in Arabic as 'Hisn al Akrad'.
} 
and acquisition. ${ }^{4}$ For a domestic audience, the exhibitions tried to interweave national and colonial consciousness by creating a narrative in which the crusades became the first chapter of France's Empire. ${ }^{5}$ To international visitors they signalled France's primacy in producing and preserving crusader architecture, as the sites were not only symbols of colonial expansion for France, but also served as proxies for broader imperial claims by other rival powers that were likewise trying to get their hands on medieval remains across the Mediterranean.

After the end of Empire, the exhibitions disappeared silently. The model of the Crac des Chevaliers is now in storage, hidden and largely forgotten. At the former museum of the Colonies, now the National City for Immigration, only the names of crusaders inscribed on the building's sidewall, behind some shrubs, offer a semi-visible reminder of the centrality the crusades once had to national colonial ideas. ${ }^{6}$ With decolonisation, the expansionist view of the nation was no longer opportune for a former colonial power. Former colonies, for their part, also erased this history as they claimed the crusader sites for themselves. The process of dissociation was further reinforced by the dispersal of the related archives across multiple countries.

This erasure of earlier entanglements by a double process of renationalisation is representative of broader trends in the historiography on heritage, which has largely been written about within national or area studies frameworks. More recently, the 'transnational turn' engendered a growing sense for the importance of former interactions, and we have been gaining a better understanding of exchanges within Europe, across the Atlantic, and between metropole and colonies in individual empires. $^{7}$ Yet we are only really beginning to map the processes of entanglement.

As a result, many chapters of colonial preservation are still unwritten, and the intra-imperial relations that framed them remain largely unexplored. Approaches to heritage in different empires have hardly been compared, nor do we know much about how imperial and transimperial networks relate to the more general internationalisation of preservation that took place over the last two centuries. In order to think

\footnotetext{
4 Maureen Murphy, Un Palais pour une Cité: Du Musée des colonies a la Cité nationale de l'histoire de l'immigration (Paris, 2007), 42

${ }^{5}$ Exposition coloniale internationale de Paris 1931. Commissariat général. Section rétrospective française, Les Colonies et la vie française pendant huit siècles (Paris, 1933).

${ }^{6}$ With the exception of Léon Pressouyre, 'Un Grand Musée en quête de sens' in idem (ed.), Le Musée des Monuments français (Paris, 2007), 36-40, the publications that accompanied the museum's reopening say little on the international and colonial aspects of its history.

7 For a broader analysis of historiographic developments see Melanie Hall (ed.) Towards World Heritage: International Origins of the Preservation Movement (Aldershot, 2011); Astrid Swenson, The Rise of Heritage: Preserving the Past in France, Germany and England, 1789-1914 (Cambridge, 2013); Astrid Swenson and Peter Mandler (eds.), From Plunder to Preservation: Britain and the Heritage of Empire, c. 1800-1940 (Proceedings of the British Academy clxxxvii, Oxford, 2013); Michael Falser, Monica Juneja (eds), Kulturerbe und Denkmalpflege transkulturell. Grenzgänge zwischen Theorie und Praxis (Bielefeld, 2013).
} 
about similarities and differences in colonial preservation, and to better conceptualise some of the entanglements that operated across national and imperial borders, this article will follow the trail of the Crusader Room in the Museum of French Monuments and investigate the preservation of 'crusader sites' in the Mediterranean from the Napoleonic wars to the interwar period, through four interconnected case studies on Malta, Cyprus, Syria and Palestine.

These 'crusader heritages' are an informative case study for comparative imperial histories, as they were not only a significant chapter in French heritage history but were also representative of a broader European interest in the crusades, which manifested itself in explorations, restorations and acquisitions by individuals and government and a thriving presence in popular culture. This interest emerged when the territories once conquered by crusaders and their successors 'again' came under the rule of the expanding European powers during the modern colonisation of the Mediterranean. The French conquered Malta in 1798, followed by British rule over the island after 1814. A second chapter began in 1878 with the British purchase of Cyprus and the Italian colonisation of Rhodes in 1912, before the heartland of the crusades came under European domination at the end of the First World War with the British Mandate in Palestine and the French Mandate in Syria and Lebanon.

The rich literature on the reception of the crusades, which has drawn attention to the relationship between historiography and national and colonial projects, is relatively silent with regard to the treatment of sites and artefacts. $^{8}$ Yet in a region of competing imperial claims, sites connected to the history of the crusades attracted the attention of all the major European powers. While the French, British, and Italians established formal empires in the Mediterranean, other European (especially German) interest in these sites was also strong. For each nation, interventions for restoration or acquisition were not limited to territories under their own rule, but extended into Ottoman territories, post-independence Greece, as well as the other European empires. These cross-cutting linkages allow us to use the crusader sites as a prism for comparing formal and informal preservation policies and for tracing the interdependencies between them. Imperial actors were of course not the only ones interested in these sites. Maltese, Greek, Turkish, Arab and Hebrew nationalists had their own agendas for their preservation or destruction, as had transnational bodies, especially the various successor organisations to the Knights of St. John.

My focus here will be on British and French colonial preservation policies, but by inscribing these within broader interactions in the Mediterranean, I hope to raise more general questions about

\footnotetext{
${ }^{8}$ See for instance Elizabeth Siberry, 'Images of the Crusades in the Nineteenth and Twentieth Centuries' in Jonathan Riley-Smith (ed.), The Oxford Illustrated History of the Crusades (Oxford, 1995); Peter Lock, The Routledge Companion to the Crusades (London, 2006), 255-72; Adam Knobler, 'Holy Wars, Empires, and the Portability of the Past: The Modern Uses of Medieval Crusades', Comparative Studies in Society and History, xlviii (2006) 293-325; Ronnie Ellenblum, Crusader Castles and Modern Histories (Cambridge, 2007).
} 
transnational and trans-imperial entwinements. Highlighting these interactions helps us understand the creation of the very category of 'crusader art', which encompassed artefacts produced over a huge span of time and space. At the same time, consideration of the local contexts in Malta, Cyprus, Syria and Palestine will also underscore the substantial variation in approaches due to differing relations with local populations.

Finally, the crusader vestiges are also a particularly intriguing case for reflecting on the construction of heritage across borders given that, for all the participants concerned, they represented a unique category between a heritage of the self and a heritage of the other. Sites of conflict and of encounter in the past as well as the present, and altered by various conquerors over the centuries, they could alternatively be seen as a European, Christian, national or colonial legacy. When viewed in relation to other monuments in the metropoles and colonies, they reveal in a pertinent way which notions of lineage informed ideas about a 'common' heritage in Europe.

\section{Malta: the legacy of the Knights}

In 1935 the British were troubled by the thought that in Egypt, 'Latin', 'and in particular French cultural ascendancy, dates back to the Crusades'. Worse still, it had 'continued constantly until the British occupation of Egypt in 1882'. ${ }^{9}$ As much as contemporary French propaganda would have revelled in this tale of uninterrupted presence, the supposed links between the crusades and modern French imperialism were only slowly established in the wake of Napoleon's Egyptian campaign. In the seventeenth century Gottfried Wilhelm Leibnitz, in the employment of the Elector of Mainz, had tried in vain to find ways to divert Louis XIV's aggression from France's Eastern border to more distant Eastern lands by mobilising the idea of completing the crusades. His memorandum was forgotten and, as it happened, Napoleon only read an abridged version after his return from Egypt. ${ }^{10}$ Modern engagement with the tangible heritage of the crusades also started not so much with reclaiming but rather demolishing the last outpost of the crusades. Seizing Malta en route to Egypt in 1798, the French portrayed themselves as liberators of the Maltese from the tyranny of the Order of the Knights of St. John, who had ruled the island since their expulsion from Rhodes in the $16^{\text {th }}$ century. To obliterate their memory, streets and places were renamed (the Palace of the Grand Masters, for instance, became Palais National), many religious houses and churches were closed and monuments were destroyed. As the French knight Louis de Boisgelin remembered:

\footnotetext{
${ }^{9}$ Sir Percy Loraine's despatch on Egypt, sent with letter from Charles Bridge to Rex Leeper, 5 March 1935, The National Archives (hereafter TNA), BW 29/3 British Council Archives. My thanks to Tamara von Kessel for drawing my attention to this reference.

10 Ellenblum, Crusader Castles, 11
} 
Everything in the public buildings, which bore the stamp of nobility, or recalled to mind the celebrated exploits performed by illustrious chiefs, was broken and destroyed. These new Goths and Vandals likewise threw down with impious hand the bust of those heroes who had graced the annals of chivalry... such an outrage as this, was not even committed by the Musulmen [sic] at Rhodes; where honourable marks still remain of the residence of the knights of St. John of Jerusalem in that island. ${ }^{11}$

De Boisgelin's condemnation of Goth and Vandals resonated with Abbé Grégoires's speeches against revolutionary 'vandalism' made three years before the conquest of Malta. During the end of the Terror, Grégoire managed to stop iconoclasm in France by redefining works of art as embodiments of the national and hence revolutionary spirit, inventing the word 'vandalism' to brandish iconoclasts as barbarians. ${ }^{12}$ The idea of the sanctity of the past did not, however, travel with the soldiers to Malta, nor did the arriving army see the heritage of the Knights as their own.

While the Maltese welcomed the end of the rule of the Knights, the French committed a mistake by treating the memory of the Knights and that of the Catholic Church as one. Following three months of French rule, the Maltese revolted. Aggrieved by French looting, the decision to strip the ecclesiastical establishments of Mdina for minting provided the trigger for massacring the French garrison. ${ }^{13}$ The Treaty of Amiens in 1802 planned to restore the island to the Knights of St. John, but the Maltese objected and opted instead for British rule, which was formally established by the Treaty of Paris in $1814 .^{14}$

Given the recent expulsion of the Knights, what was then to happen to their legacy? Intuitively, it would seem unsurprising if neither the Maltese nor the British colonial administration immediately valued the Knights' 'heritage' as their own. Yet British travellers who stopped in Malta on their way to Egypt, the Holy Land or India romanticised it. Even half a century later, 'very few of the numerous Englishmen who visit Malta seem to have any idea of the archaeological treasures of the Phoenicians', ${ }^{15}$ and 'very many of [the island's] treasures have escaped notice, and some of priceless value have been neglected and ultimately lost'. ${ }^{16}$ By contrast, 'all the world' seemed to 'know Malta' and its 'noble

\footnotetext{
${ }^{11}$ Louis de Boisgelin, Ancient and Modern Malta (London 1804), III, pp. 98-99, quoted in Dennis Castillo, "The Knights cannot be admitted": Maltese Nationalism, the Knights of St. John, and the French Occupation of 1798-1800', The Catholic Historical Review, Ixxix (1993), 445-6.

12 Henri Grégoire, Patrimoine et Cité, ed. Dominique Audrerie (Bordeaux, 1999).

${ }^{13}$ Carmel Casser, A Concise History of Malta (Malta, 2002), 141-3; Carmel Testa, The French in Malta, 1798-1800 (Malta, 1997).

${ }^{14}$ Castillo, "'The Knights"'.

${ }_{15}^{15}$ A.H. Sayce, 'The Antiquities of Malta', The Times, 5 Feb. 1883, 12.

${ }^{16}$ Count Bologna Strickland, 'The Antiquities of Malta', The Times, 13 Feb. 1883, 8.
} 
palaces, formerly inhabited by the famous knights'. ${ }^{17}$ While it was now the Governor of the island (and for one winter in 1838 the Queen Dowager) who resided in the place of the Grand Masters, ${ }^{18}$ in the visitors' imagination it was 'the Grand-Master and all his knights' who 'still possessed the island' (fig.1). ${ }^{19}$ Preservationists across the British Empire complained that the authorities did too little to protect this heritage - or any heritage - on the island, which mirrored the prevalent attitude towards ancient monuments in Britain and the colonies more broadly. As Major Keith, Archaeological Surveyor for Central India, pointed out in 1888 in a report comparing India and Malta for the Society for the Protection of Ancient Buildings in London: 'Neither in India nor in other dependencies has our Government hit on a systematised plan to check destruction or repress vandalism'. ${ }^{20}$

Letters to The Times in London often pointed out that the government lagged behind private initiatives in matters of preservation. A Roman villa was excavated and placed under the guardianship of a custodian at the public expense at Civita Vecchia (Mdina), and the Maltese antiquarian and librarian Dr Caruana drew up a report on the antiquities of Malta at the suggestion of the Government. ${ }^{21}$ In addition, 'many treasures of the latter period of the Knights of Malta' were preserved by individual Maltese. But despite the foundation of a learned society inventorying monuments, ${ }^{22}$ a proposal by Caruana for the foundation of a national museum, as well as public calls in the London press in the early 1880s that 'a Government official should be responsible for at least preserving a record of existing and future archaeological discoveries' in Malta as 'a subject of general interest', no institution was founded. ${ }^{23}$ In 1888, Major Keith tried to alert Sir Lintorn Simmons, Governor of Malta:

I invited his attention to the fact that, owing to the want of conservative measures, a dependency which had a varied history extending back to 1400 B.C., including the dominion of the Phoenicians, Greeks and Romans, Saracens, and Maurs, to say nothing of the chivalrous mediaeval Knights of Malta, had been for years systematically plundered and depleted of its valuables. His Excellency [...] listened with much attention, and I hope my representations may lead to the forming of a national museum. Had such a museum

\footnotetext{
${ }^{17}$ Half Hours in the Holy Land. Travels in Egypt, Palestine, Syria (London, 1898), 1214.

18 Despatch of 7 Dec 1838, Centre des Archives Diplomatiques, Nantes (hereafter CADN), 166PO/D45/2 Constantinople, Correspondence Avec les Echelles, Serie D Malte.

${ }^{19}$ Half Hours in the Holy Land, 12-14.

${ }^{20}$ SPAB, Annual Report (1888), 57-8; SPAB Archives, London, Committee Minute Book, $26^{\text {th }}$ July 1888.

${ }^{21}$ A.H. Sayce, 'The Antiquities of Malta', The Times, 5 Feb. 1883, 12. More broadly see Nicholas C. Vella and Oliver Gilkes, 'The Lure of the Antique: Nationalism, Politics and Archaeology in British Malta (1880-1964)', Papers of the British School at Rome, 69 (2001), 353-384.

${ }^{22}$ National Library of Malta, Ms. 588, Archaeological and Geological Society of Malta.

${ }^{23}$ Count Bologna Strickland, 'The Antiquities of Malta', The Times, 13 Feb. 1883, 8.
} 
been formed at the time the Island was ceded to England, Malta would have possessed a collection of antiquities second to none in Europe. ${ }^{24}$

In a climate where the preservation of heritage was increasingly proclaimed to be 'a yardstick for a people's cultural attainment', such indifference could undermine British criticisms of the treatment of heritage by indigenous populations in India or Egypt, and harmed the argument that British guardianship was needed until indigenous populations would mature to take responsibility. ${ }^{25}$ Given the 'neglect of antiquities of Malta' and the 'shortcoming of our own in the countries subject to us', it was unsurprising, an editorial in The Times concluded, 'If, then, the Egyptians are indifferent to the past, they may certainly plead Western example in their defence. It is in fact, Western examples, which directly or indirectly is the root of all the mischief. ${ }^{26}$

In many ways, this story of neglect is much exaggerated. If we turn from the metropolitan perspective to Maltese records, it becomes apparent that although no particular institution for preservation was founded and no Antiquities Law or Monument Act was passed before the early $20^{\text {th }}$ century, there was nevertheless a strong sense for the importance of preservation within the colonial administration. Malta was singular among our case studies in that the Crown inherited all the buildings of the Knights, making it the owner not only of the fortresses but also of the Palace of the Grand Masters and of various Catholic churches, including St. John's Co-Cathedral in Valetta. Already in 1801 Downing Street gave the Civil Commissioner for the affairs of Malta detailed instruction to familiarise himself with laws and customs put in place by the Knights. Mindful of what the vandalism of churches had cost the French in Malta, subsequent British governors stressed in their despatches to London the importance of preserving St. John's Cathedral, as neglect might provoke the ire of the Maltese. Several careful repairs and restorations were executed throughout the century and preservation was conducted as a collaborative project between members of the Maltese and Colonial elites. ${ }^{27}$

But without a special bureaucracy in charge of monuments, not much was publicised about these conservation policies. It is significant for the broader story here that the history of neglect only really became a matter of public concern in the 1930s as preservation became a matter of imperial competition at 'a time of emerging nationalist political

\footnotetext{
${ }^{24}$ SPAB, Annual Report (1888), 60.

${ }^{25}$ See Astrid Swenson, 'The Heritage of Empire', in Swenson, Mandler (eds.), From Plunder to Preservation.

${ }^{26}$ The Times, 5 Feb 1883, 9 (Leader).

${ }^{27}$ Lord Hobart to Charles Cameron, London, 14 May 1801. National Archives of Malta (hereafter NAM) GOV 1/2/1; Sir Thomas Maitland to Earl Barthurst, Malta, 27 January 1814, NAM, GOV 1/2/1; Bouverie to Lord John Russel, Malta 7 July 1840, NAM, GOV $1 / 2 / 19$, fols 190-201; More O'Ferrall to Earl Grey, Malta $5^{\text {th }}$ October 1848, NAM, GOV 1/2/23, fols 647; Marchant to Bulwer Lytton, Malta, 27 November 1858, NAM, GOV $1 / 3 / 927$, fols $377-78$.
} 
activism and local political flirtation with fascist Italy'. ${ }^{28}$ The restoration of the City of Rhodes, which followed Italian conquest, created fears that the Italians might also use the Knights' heritage to claim the 'return' of Malta into Italian hands. ${ }^{29}$ As a result, the Lieutenant Governor of Malta, Sir Harry Luke, initiated a widely publicised restoration campaign, including an embellishment of the city of Mdina in sicolo-norman style. ${ }^{30}$ This awakening to the cultural-political importance of public acts of preservation becomes even more apparent when we turn our attention from Malta to Cyprus.

\section{Cyprus: the heritage of kings}

There are many similarities between the treatment of monuments in Malta and Cyprus, but as Cyprus was integrated into the Empire much later and with a different status, there were also significant differences. The link to the crusades was at one level more distant (in terms of time elapsed) and at another level more proximate (in terms of possibilities to construe national links). Richard Lionheart's conquest of the Island and his marriage in a hilltop castle made it (as noted repeatedly by Sir Harry Luke, who spent part of his career before and after Malta in Cyprus) Britain's oldest colony, and the only one ever to have witnessed a Royal wedding. ${ }^{31}$ Cyprus' history, however, also provided ample chapters for other national reclaimings. The French in particular focussed on the thirteenth- and fourteenth-century Lusignan dynasty, and the Italians on the Venetian occupation after 1489. At the same time, there was not such a direct transmission of property rights as in the case of Malta. Some castles became government property, but most secular buildings were privately owned, while the former Latin ecclesiastical buildings had largely been transformed into Orthodox churches or mosques and were in the hands of the religious authorities (fig.2).

Unlike in Malta, both the British authorities in Cyprus as well as the British public initially paid little attention to the island's architectural treasures. On the contrary, in the 1890s Famagusta's medieval structures were being systematically destroyed to provide stone for the

\footnotetext{
${ }^{28}$ Paul Sant Cassia, 'Tradition, Tourism and Memory in Malta', The Journal of the Royal Anthropological Institute, v (1999), 248.

${ }^{29}$ On the reclaiming of Rhodes and the restoration of the Hospitaller's heritage between 1913-24 see Mia Fuller, Moderns Abroad. Architecture, Cities and Italian Imperialism (London, New York, 2007), 78-9.

30 H. Luke, Malta: An Account and an Appreciation (1949), (London, 1960), 99-101; Cassia, 'Tradition, Tourism and Memory', 248. On the perception of neglect until Sir Harry Luke's restorations see for instance a paper read by Clakson to the Society of Antiquaries of London, December 36. Museum of the Order of St. John's, London Archives (hereafter MOStJ), Sir Harry Luke Papers, Malta.

On the development of conservation in Malta see TNA, WORK 14/2335, Preservation of ancient monuments in Malta. In turn, British interest triggered French curiosity, see CADN, 350PO/3/6 La Valette, 'Autres Affaires'.

${ }^{31}$ See press clippings, publications and talks in MOSt.J, Sir Harry Luke Papers.
} 
building of Port Said in Egypt. ${ }^{32}$ Among the few metropolitan voices that spoke out against this was William Morris' Society for the Protection of Ancient Building (SPAB). Founded in 1877 to protest against restorations in England, the SPAB also championed the preservation of buildings all over the world and started to intervene in Cyprus soon after the transfer to British control. The Earl of Wharncliffe, a prominent Conservative member of the Society's Committee, was asked for advice on how to influence the government to initiate a survey of medieval buildings, but efforts to contact Lord Salisbury, the Foreign Secretary, as well as his nephew and private secretary Arthur Balfour, yielded no results. $^{33}$

Interest in Cyprus' architectural heritage was spurred less through English endeavours than through the activities of foreign medievalists. Germany and France simultaneously sent scholars on scientific missions to study Cyprus's gothic buildings, who in fact met on one occasion after the German scholar requested to 'know his enemy'. ${ }^{34}$ But it was undoubtedly the Frenchman, Camille Enlart, who lastingly put Cyprus on the scholarly map through the publication of L'Art Gothique et la Renaissance en Chypre in 1899, which led to international outcries over the British government's failure to protect Cypriot monuments. ${ }^{35}$ In France, it fostered the view that French crusaders had brought Gothic Art to the island and that these monuments were therefore part of the national patrimony. ${ }^{36}$ At the same time, a number of pieces appeared in the Italian press criticising the British in Cyprus, in particular in light of the highhanded British campaign to save St. Mark's of Venice from its Italian restorers, which William Morris and the SPAB had led more than twenty years earlier. The Gazzetino of Padua, for instance, wrote:

Some years ago, when the restorations of St. Marks were commenced, and carried on with such care, the English made a devil of a row [sic] with articles in journals, meetings etc. to signify their disapproval. Curiously now the English are selling the stones of ancient Famagusta for the construction of Port Said ... who in Italy cares for archaeology - and who does not care somewhat - should know what is British respect for the glorious monuments of the Italo-Greeks, and that whilst they are being demolished with the pickaxe, the English soldiers are

\footnotetext{
${ }^{32}$ Frank C. Sharp, 'Exporting the Revolution: The Work of the SPAB outside Britain 1878-1914', in Chris Miele (ed.), From William Morris: Building Conservation and the Arts and Crafts Cult of Authenticity, 1877-1939, (New Haven, London, 2005), 204.

${ }^{33}$ See ibid and Earl of Wharncliffe to Newman Marks, 4 Aug. 1878, SPAB Archives, 'Cyprus'.

${ }^{34}$ Archives Nationales, Paris (hereafter AN), F17/2960, Mission de Camille Enlart en Chypre.

${ }^{35}$ Sharp, 'Exporting the Revolution, 204.

36 On Enlart's place in debates about the origins of the Gothic see Anne-Cécile Celimon-Paul, 'Camille Enlart', in Philippe Sénéchal, Claire Barbillon (eds.), Dictionnaire critique des historiens de l'art actifs en France de la Révolution à la Première Guerre mondiale", Institut National d'Histoire de l'Art Paris, (2009), http://www.inha.fr/spip.php?article2309, accessed 27 Jan. 2013;
} 
looting the old cemeteries. The Cypriots murmur 'worse than the Turks! ${ }^{37}$

The Cypriot murmur soon turned into a loud protest. In reaction to an attempt by Chamberlain to blame the state of monuments on the lack of interest shown by the Cypriots in the preservation of the antiquities of their island, ${ }^{38}$ the Legislative Council of Cyprus wrote an address to the high Commissioner, also reprinted by The Times:

With respect of the Cyprus antiquities of universal fame, the council desires to remark that the Cypriotes will be for ever irreconcilable to the despoliation thereof which has been carried on from the time of the English occupation to these days, for which the Cypriotes consider the Government to be chiefly responsible, because they under their very eyes, have suffered the glorious temples and tombs of the ancestors of the Cypriotes to be despoiled of their most previous objects. The Council is very glad to see that the Government has well perceived the very great interest which is taken by the Cypriotes in their antiquities, which, of course, is not unconnected with their noble descent; and the Council anxiously awaits the efficient measures that will be submitted for the purpose, which will be favoured by the Council with all its attention in the conviction that such measures, which passed by the Council, will, now that the feelings of the Cypriotes have been sufficiently understood, receive the necessary sanction as soon as possible. ${ }^{39}$

Over the following months, as voluntary groups in Britain took a number of measures to highlight the issue, a growing consensus developed in the major British newspapers that the government should do more to protect Cypriot monuments. ${ }^{40}$ George Everett Jeffery, architect of St. George's Anglican Cathedral and College in Jerusalem, who had worked as an Inspector of Public Works in Cyprus in 18991900 and had assisted Enlart in Cyprus in 1901, was called back to a newly created post of Curator of Ancient Monuments. ${ }^{41}$ One of his first acts was to record the danger posed to many prominent medieval buildings and the destruction of structures researched by Enlart. He also approached the SPAB, the National Trust and other learned and

\footnotetext{
${ }^{37}$ Gazzetino of Padua, 14 April 1901, translated by Jeffery and forwarded to the SPAB from Venice, 25 April 1900, SPAB Archives, 'Cyprus' repr in Pilides, George Jeffery, II, p. 589-90

${ }^{38}$ House of Commons Debate, 26 May 1902 (M. Chamberlain).

39 'Cyprus and its Antiquities', The Times, 24 June 1902, 13.

40 For instance 'The Neglected Treasures of a British Crown Colony', Illustrated London News (hereafter ILN), 11 Aug. 1934, 221; press clippings, SPAB Archives, 'Cyprus'; Sharp, 'Exporting the Revolution', 205.

${ }^{41}$ Despina Pilides, George Jeffery: His Diaries and the Ancient Monuments of Cyprus, 2 vols. (Lefkosia, 2009), 83. K.W. Schaar, M. Given, and G. Theocharous, Under the Clock: Colonial Architecture and History in Cyprus, 1878-1960 (Nicosia, 1995).
} 
voluntary bodies in Britain, which would eventually lead to collaboration over the next three decades. ${ }^{42}$ Mobilising the political connections of David Lindsay, heir to the Earl of Crawford and Balcarres, a first campaign resulted in the successful demise of plans to demolish Famagusta's medieval seawall to make way for a harbour and the railway.

Over the following years, the collaboration between Jeffery, Balcarres and the SPAB thwarted not only colonial and local vandalism, but also some foreign intervention, in particular a restoration funded by the French government in Famagusta that would have stripped Venetian features from a number of Lusignan buildings in an attempt to restore them to their state under the French dynasty. ${ }^{43}$ Jeffery believed that 'the memorials of 100 years of Italian occupation of Cyprus should be religiously preserved and in no case sacrificed to French interests'. ${ }^{44}$ Imbued with Ruskinian principles, Jeffery and the SPAB opposed all forms of stylistic restoration and tried to protect all historic remains rather than just those that could serve a particular artistic or nationalist school.

A general shift in attitudes within the government also took place between 1901, when Jeffery complained that 'nothing can be expected from them', and 1904, when Sir W. Heynes Smith, the High Commissioner for Cyprus, 'expressed approval of any scheme for enlisting' voluntary societies in Britain 'in the endeavour to preserve all that remains of the remarkable artistic past of Cyprus'. ${ }^{45}$ An Antiquities Law was passed in 1905, which was primarily designed to regulate the excavations and export of archaeological objects, but which also enabled the classification of buildings as Ancient Monuments. Although it had stronger compulsory clauses than the Ancient Monuments legislation in Britain, it stopped short of religious buildings. The gothic cathedrals in Famagusta and Nicosia, as well as many other Latin churches that had been converted to Orthodox churches or mosques, remained under the control of the Moslem Board of Turkish Commissioners for Charitable and Religious Purposes (Evcaf) or the Greek Orthodox bishop. There were also limits due to private ownership, which is well illustrated by the castle of Kolossi, the former headquarter of the Knights Hospitallers. The well-preserved fifteenth-century keep, containing numerous medieval carvings related to Hospitaller sculpture at Rhodes, was owned by the Anglo-Egyptian Allotment Company and used for storage. In 1909, Jeffery learned that the property was available for sale and the SPAB offered $£ 400$ for the castle, but was outbid by a local merchant who transformed the castle into a residence. Subsequently, the Venerable Order of St. John's became interested in this 'ancestral' home, and acquired a small share. Noticing the interest,

\footnotetext{
42 SPAB, Annual Reports from 1902 onwards; Pilides, George Jeffery, I and II, passim.

43 Sharp, 'Exporting the Revolution', 207; MAP 81/098/1, 'lle de Chypre, Antiquités franques de Famagouste'; see also TNA, FO 370/1027, 'Preserving of French monuments by Government of Cyprus'.

44 Jeffery to Thackery Turner, 16 May 1901, SPAB Archives, 'Cyprus'.

45 Jeffery to Thackery Turner, 15 June 1901 and 21 Oct. 1904, SPAB Archives, 'Cyprus'.
} 
the main owner sold off parts of the castle among the villagers to drive up the price in case the Order or the government were willing to buy it. As a result, it took decades of negotiations before the Order and the government emerged as sole owners. ${ }^{46}$

In the midst of war in 1915, the SPAB expressed hopes that 'One of the effects of this otherwise disastrous War is that Cyprus has come entirely under the control of the British Government, with the result that the Curator of Ancient Monuments, Mr George Jeffery, will be in a better position to exercise his authority than when the country was under Turkish influence'. ${ }^{47}$ Whether one sees the following years as a period of increasing preservation or of continuous vandalism and neglect is a question of perspective, however. The new status as a Crown Colony did not bring with it an immediate shift towards the preservation of ancient monuments. Jeffery returned to the Island after a brief English interlude with a bigger salary, but still a very small budget at his disposition. In the early 1930s, Jean Ricard, the French Consul in Larnaca, repeatedly complained to Paris about the neglect of the 'Frankish antiquities' by the British authorities. Throughout his despatches Ricard continually emphasized the need to improve France's reputation in the region, not least because of an ever greater Italian presence. ${ }^{48}$ Given that 'the preservation of these moving vestiges is especially interesting for us, as they pay testament to the grandness of works conceived and executed by French masters', ${ }^{49}$ the Consul deplored the lack of repairs, the disfiguration of ancient buildings by modern constructions, and the total abandon of Jeffery's small lapidary museum of gothic remains. He was especially scornful about Jeffery ('a very old man of somewhat doubtful competence') and hoped that once he retired, better care would be taken to preserve the 'important artistic heritage given to generations of amateurs and scholars by the French dominance in Cyprus'. ${ }^{50}$

The French Foreign Office consulted Paul Deschamps, expert on crusader architecture and intellectual heir of the recently deceased Camille Enlart, and René Dussaud, curator at the Louvre, about how to approach this diplomatically delicate matter. Both had recently curated the section on the crusades for the 1931 Colonial Exhibition in Paris. Dussaud pleaded caution, pointing out that the recent tension between the British authorities and the Cypriot population meant that any intervention by the French authorities might not be seen for its 'purity of motives'. He assumed that Sir Ronald Storrs, formerly in charge of Palestine and now governor of the island, could surely not be aware of the problems, otherwise they would not have been ignored. He

\footnotetext{
${ }^{46}$ Sharp, 'Exporting the Revolution', 208-10; CSA, SAI 1242/13/1; MOSt.J, Sir Harry Luke Papers, 50/3 C.

${ }_{47}^{47}$ SPAB, Annual Report (1915), 32.

48 See despatches 1931-34, CADN, 345 PO1 Larnaca, Consulat et Agence Consulaire.

49 Jean Ricard to Président du Conseil, Ministre des Affaires Etrangères, 24 Mar. 1932, Mediathèque de l'Architecture et du Patrimoine, Paris (hereafter MAP), 81/98/1, 'île de Chypre'.

50 Ibid.
} 
suggested getting a better idea of the situation by asking the archaeologist in charge of excavations near Famagusta, M. Schaeffer, to visit the medieval monuments and record their state of conservation. Schaeffer would then have the necessary authority to signal to the British government which measures were the most urgent to take. ${ }^{51}$

In his comments on the state of the 'monuments erected on the island of Cyprus by the Princes of French stock', Paul Deschamps likewise drew a much less negative picture than Ricard had done. Based on his visit to the island three years earlier, he was full of praise for Jeffery. ${ }^{52}$ $\mathrm{He}$ also stated that the former cathedrals of Famagusta and Nicosia were in a relatively good state, even if only very modest sums were available. He conceded, however, that 'The English do not seem to exploit intensely the island's resources' ${ }^{53}$ For him this was clearly due to a lack of national interest:

The English don't have the same immediate reasons to be interested in the medieval monuments erected in Cyprus as we do, because these monuments are not related to their past, but belong essentially to our national history and our national art. ${ }^{54}$

Like his colleague Dussaud, Deschamps was not sure how the British authorities would react to suggestions by foreigners about how to care for the island's ancient monuments. Despite these pleas for caution, the Ministry of Public Instruction in France eventually decided to offer the Cyprus government a considerable sum for the 'preservation and restoration of the French mediaeval monuments in the island'. Although it was coldly rebuffed, it had important consequences. ${ }^{55}$ The fact that other European countries perceived a link between medieval remains and modern claims provided powerful ammunition for those who were campaigning for preservation in Cyprus and in Britain. ${ }^{56}$ The Colonial Office and the Cyprus Government were forced to react, as British, local and international voices joined each other. ${ }^{57}$ Time and again, the important monuments, 'initiated by our own Richard of the Lion Heart, developed by the French Lusignan Dynasty, and ended by a Venetian hegemony', ${ }^{58}$ of which there were 'enough to fill two volumes of Dr. Enlart's great work, "L'Art Gothique et la Renaissance en Chypre"' were

\footnotetext{
${ }^{51}$ René Dussaud to Paul Léon (Directeur General des Beaux Arts) c/c M. le SousSecretiare d'Etat des Beaux Arts, Paris, 5 July 1932, MAP 81/98/1 'lle de Chypre'.

52 Paul Deschamps to Sous-Secretiare d'Etat des Beaux-Arts, 12 July 1932, MAP 81/98/1 'île de Chypre'.

53 Ibid.

54 Ibid.

55 Sir George Hill to Mogabgab, Aug, 1934, TNA, CO 67 253/2, Doc. 80, qu. in Charlotte Roueché, 'The Prehistory of the Cyprus Department of Antiquities', British School at Athens Studies, viii, MOSAIC: Festschrift for A. H. S. Megaw (2001), 160.

${ }^{56}$ Roueché, 'Prehistory', 155-166.

57 TNA, FCO 141/2475, 'Cyprus: measures for preservation of historic and pre-historic monuments in Cyprus'.

${ }^{58}$ Norman H. Baynes, William H. Buckler, W.D. Caroe, F.H. Marshall, John L Myres, Steven Runciman, George Francis, Harold Gibraltar, 'Antiquities of Cyprus', The Times, 22 Sept. 1933, 8
} 
now described in the pages of major newspapers along with vociferous calls for the government-'apparently callous in this important matter'to reconsider its 'negative attitude'. It was 'time that Great Britain, which has inherited this responsibility with the direct control of the Island, should play her part as Italy is doing in Rhodes and Tripoli, and France in Syria, Algeria, and Tunisia'.

Even more strongly than in Malta, one can observe how the international situation motivated preservation in Cyprus. In a confidential report to the Secretary of State for the Colonies, Sir George Hill, Director and Principal Librarian of the British Museum, warned that: 'In the shouldering of such a moral responsibility the Italian administration in Rhodes and the French in Syria offer examples which put the British in Cyprus to shame. The French and Italian governments understand the value in imponderable assets - such as a reputation for enlightenment of a proper care for the historical monuments of the countries, which they have undertaken to govern'. ${ }^{59}$ In the national press the same argument appeared repeatedly. Despite hard economic times, 'the loss of such priceless treasures of antiquity is likely in the long run to lead to a lack of prestige in the world of culture as irreplaceable as are the treasures themselves if allowed to founder.' ${ }^{, 60}$ 'The national reputation for pietas', 'for a decent regard for the noble relics of the ancients, would suffer'. ${ }^{61}$ Efforts were redoubled after the invasion of Abyssinia fuelled fears about the aggressiveness of Italian imperialism. ${ }^{62}$ In 1933 , a 'belated beginning' was thus made with the formation of a Cyprus Committee under the chairmanship of Lord Mersey and with the approval of the Colonial Office and the Government of the Island. It raised awareness through the press, learned talks and exhibitions, and started fundraising. The new Cyprus Monument Fund solicited donations from Britain to accomplish the 'very necessary work analogous to that accomplished years ago in Rhodes', where, as the Committee explained in its preliminary appeal, the Italian Government has "transformed a city of dirt and ruin into one of the sights of the East"'. The same lesson was drawn from Syria, where "'a wise but lavish expenditure by the French yearly discovers, restores and preserves the famous relics of the past"' 63

The preservation of monuments in Cyprus draws thus attention to the importance of international competition between the French, British and Italians in the Mediterranean. What, then, are we to make of the many assertions about the differences between French versus British attitudes to the crusader sites as national heritage? Were the developing preservation policies only reactive rather than based on identification

\footnotetext{
59 'Report on the condition of Antiquities in Cyprus', $9^{\text {th }}$ May 1934, Cyprus State Archives, SAI 728/34, fol 87.

60 'Antiquities of Cyprus', The Times, 22 Sept. 1933, 8

61 'An Appeal for Cyprus', The Times, 24 Jan 1935 (Leader).

62 Roueché, 'Prehistory', 155-166.

63 Cyprus Committee for the Preservation of Ancient and Medieval Monuments, Cyprus. An Appeal to preserve its Historic Antiquities (s.d., s.p.), the passages was often reprinted in the later reports of the committee and in the press, e.g. 'The Antiquities of Cyprus. Work of Preservation', The Times, 14 Jan 1936, 13.
} 
with these sites? Not quite. Those Britons who were not indifferent to monuments altogether, showed incontestable interest in the 'English' past of the Island. Jeffery strongly romanticised Richard I, ${ }^{64}$ and, shortly after starting his post as Curator of Ancient Monuments, wrote to London to encourage more interest in the Latin past and to prevent the control of sites from being passed to a 'native committee'. The sites should be preserved and if possible be acquired 'by the representatives of the race to which they historically belong. In other words, I think that a little English interest of a solid proprietary kind would be a good thing in Cyprus', above all to establish the Englishness of the Island against the anti-colonial nationalists' 'imaginary Homeric parentage'. ${ }^{65}$ In the 1930s, this idea was taken up by the Governor of Cyprus. Soliciting help from the Order of St. John for the preservation of Kolossi in 1935, Sir Richmond Palmer suggested that 'the fact that the British Realm of the Order should take an active interest in Cyprus is an asset of very considerable value from an Imperial and National point of view, as cementing further connections of Cyprus with England which dates from the days of Richard I'. ${ }^{66}$ During the same years, Kolossi also appeared on the Cypriote stamps (fig.3). Overall, however, such blatantly instrumentalist statements were relatively rare. Those people who cared for ancient buildings tended to campaign for monuments of all periods and regardless of their supposed national origin - if anything the Byzantine monuments were perhaps of greater concern to British scholars than the Latin ones. ${ }^{67}$ When we place the competition over Cyprus's 'crusader' buildings in relation to other Mediterranean areas, it also becomes apparent that a more pronounced difference between French and British attitudes concerned acquisition rather than symbolic appropriation. The French state made considerably greater efforts since the late nineteenth century to restore and acquire monuments associated with the 'national' past, regardless of who ruled the territories in which they were found, whether British or otherwise. France's ambassador to Constantinople acquired another monument associated with the crusades, the Auberge de France in Rhodes, at a moment when control of the island passed from Ottoman to Italian hands, despite Italian, Greek and Turkish protests against such interference. ${ }^{68}$ This acquisition set a precedent for wider interventions after 1920, as the mandatory system of the League of Nations brought a whole range of older and arguably more significant crusader sites under French control.

\section{Syria: 'national heritage' reclaimed}

\footnotetext{
64 George Jeffery, Cyprus under an English King in the twelfth Century: The Adventures of Richard I and the Crowing of his Queen in the Island (Nicosia, 1926).

${ }^{65}$ George Jeffery to Hugh Thakerey Turner, 6 January 1911, repr. In Pilides, George Jeffery, II, p. 402-3

${ }^{66}$ Sir Richmond Palmer to Lord Scarborough, 1 January 1935, Cyprus State Archives (hereafter CSA), SAI 1242/13/1; see also, MOStJ, Sir Harry Luke Papers, 50/3 C.

67 For instance, Cyprus Committee for Preservation of Ancient and Medieval Monuments 'Cyprus. An Appeal to preserve its Historic Antiquities (s.d, s.I),

${ }^{68}$ CADN, 569PO1/16 Rhodes Vice Consulat, 'Auberge de France'.
} 
French interest in the crusader sites in the Levant was longstanding, and had been fostered through a series of scientific missions during the nineteenth-century. ${ }^{69}$ Given their interventionist policies elsewhere, it is all the more interesting that, when given the Mandate over Syria, French officials underlined the need to be 'very indirect' in the establishment of a French Archaeological Institute and Antiquities Service. In order not to alienate the locals, it was argued, the Institute had to operate almost more indirectly than the French Antiquities service in Egypt under British dominance. $^{70}$

And yet within the next fifteen years, the most extensive intervention on a crusader site was to take place, slowly but steadily pushed by the same group of scholars already encountered in Cyprus. Given his expertise in crusader art on Cyprus, Enlart was invited in 1921 by the High Commissioner General Gouraud to conduct a survey of monuments in Syria and Lebanon that culminated in the publication of Les Monuments des Croisés dans le Royaume de Jérusalem, a 'last chapter of a vast inquiry that he began thirty years before on the expansion of mediaeval French art in foreign lands', and a sequel to his earlier work on Cyprus. ${ }^{71}$

After Enlart's sudden death in 1927, Paul Deschamps, a graduate of the École des Chartes and Enlart's assistant at the Museum for Comparative Sculpture in Paris, was simultaneously made his successor at the Trocadéro and in Syria. ${ }^{72}$ Setting sail for the Levant "very anxiously", as his knowledge of medieval military architecture was according to his own account "very modest"', 73 he subsequently turned himself into "'one of our last crusaders"'. ${ }^{74}$ A devout Catholic, he was inspired by a romantic vision of the period and rejected any criticism of the crusaders. ${ }^{75}$ During the Mandate, Deschamps laboured tirelessly for the French government to obtain the Crac des Chevaliers, arguing that this 'essentially French monument' and 'national heritage' needed to be

\footnotetext{
69 Jaroslav Folda, Crusader Art in the Holy Land: From the Third Crusade to the Fall of Acres, 1187-1291 (Cambridge, 2005), 1-7; AN, F17/2936/A Mission de Louis Batissier en Orient, 1846.

${ }^{70}$ Note 'Sur la Creation d'un Institut Archaeologique de Syrie', MAP, 81/98/3 'Syrie, Creation d'un Institut archaeologique'. On the antiquities service see, Pierre Fournié and Jean-Louis Riccioli, La France et le Proche-Orient, 1916-1946 (Tournai, 1996), 138-68; Rolf Stucky, 'Henri Seyric - Engagierter Archäeologe und Verwalter des Antikendienstes während der Mandatszeit', in Charlotte Trümpler (ed.), Das Grosse Spiel. Archäologie und Politik zur Zeit des Kolonialisms, 1860-1940 (Cologne, 2010).

${ }^{71}$ Trans. in Mayer Schapiro, Review of 'Les Monuments des Croisés', The Art Bulletin, xii (1930), 301-2.

72 Jean Richard, 'Notice sur la vie et les travaux de Paul Deschamps, Membre de l'Académie', Comptes-rendus des séances de l'Académie des inscriptions et belleslettres, cxxxv (1991).

${ }^{73}$ quoted in Richard, 'Notice sur la vie', 342.

74 according to Gustave Dupont-Ferrier quoted in ibid, 345. See also Remise a M. Paul Deschamps de son Epée d'Academicien, le 26 Octobre 1943 au Musée des Monuments Français, AMN, O30 471 Paul Deschamps.

${ }^{75}$ As late as the 1970s, he replaced critical comments about the crusaders by a prefacer to one of his books by '...'. Richard, 'Notice sur la vie', 345.
} 
rescued from the indigenous people who used it as a quarry to build houses and lived on the site with their herds. ${ }^{76}$

The French Foreign Office negotiated that the Alawite State would offer the Crac as a gift to the French State, subject to the sum of one million Franks as indemnities for the expulsion of the indigenous inhabitants. The sum (plus an additional 2.2 million Franks for restoration and maintenance) was initially approved, ${ }^{77}$ but then suddenly withdrawn by a subsequent Minister of Finance because of the Depression. In their renewed campaign, Deschamps, the Fine Arts Administration and the Foreign Office once again underlined not only the importance of the site as French national heritage and the threat posed to it by the indigenous population but also pointed out that failure to acquire it would give way to the possibility of 'the Knights of Malta that is to say Italy', claiming the site. ${ }^{78}$ Given the 'propagandistic value' of the site, the international rivalry argument proved successful and the Crac was acquired. The acquisition was accompanied by a vast publicity effort in France ranging from the Colonial Exhibition, the Colonial Museum and the Museum of French Monuments to radio shows, popular books and reproduction on postcards and even chocolate advertisements (fig.4). ${ }^{79}$

The ensuing restoration, which removed the settlers, destroyed their habitation and restored the site to its 'original' appearance, was extraordinary not only in its scale but also in its invasive nature, which was unusual for the period by international standards. It seems far more reminiscent of mid-nineteenth century restorations than of the contemporary efforts in interwar France. Nineteenth century 'stylistic restoration' had followed the idea of resurrecting an ideal state by removing not only later architectural additions from heritage sites but often also their current inhabitants. For instance, in the Roman amphitheatres in Nimes, Orange or Arles, medieval houses built inside the arenas were removed. Under the influence of Ruskinian thinking, conservation theory had since changed to preserve all elements of a site as part of the historic record rather than privileging an idealised vision of one period. Although the Athens Charter codified these conservation principles as international standards in the interwar period, stylistic restoration remained widespread in a colonial context. The Antiquities Services in Syria, for instance, similarly decided to demolish a Christian church to free the Roman temple of Baalbek and evacuated

\footnotetext{
76 The expression 'patrimoine national' is recurrent in the letters Deschamps wrote to the various government agencies involved in the negotiations and was taken up by the Administration des Beaux-Arts, MAP, 81/98/3, 'Syrie, Acquisition du Krak'.

77 'Project de loi ayant pour objet l'acquisition par l'Etat du Crac des Chevaliers appartenant a l'Etat des Alaouites (Syrie)', MAP, 81/98/3, 'Syrie, Acquisition du Krak'.

${ }^{78}$ Presidence du Conseil, Affaires Etrangères to Sous-Secretaire D'Etat des BeauxArts, 8 Dec 1932, MAP, 81/98/3, 'Syrie Aquisition du Krak'. For the details of the acquisition, CADN, 188PO/C/30-33 Damas (ambassade) and Archives des Affaires étrangères, La Courneuve, 50CPCOM/601 Correspondence Politique et Commerciale E - Levant, Syrie Liban 1918-1940.

79 On the international reception of the acquisition for instance, 'The Crusaders Greatest Castle Ceded to France for Preservation', ILN, 20 Oct 1934, p. iv.
} 
the entire population that had settled in the Bel temple of Palmyra. ${ }^{80}$ Such thorough-going restorations were not limited to the French Empire. Across the border in the British Mandate, Jerusalem had just witnessed a similar stylistic restoration of its medieval city walls under the auspices of the Arts and Crafts designer C.R. Ashbee. ${ }^{81}$

\section{Palestine: no dream come true}

The treatment of the crusades under the British Mandate in Palestine was, however, very different from France's outspoken reclaiming of sites as national heritage in Syria. Preparing the advent of British rule in Palestine, the British authorities issued a confidential D-notice in 1917 explicitly outlawing any reclaiming of the crusaders in order not to alienate Muslim supporters:

The attention of the Press is again drawn to the undesirability of publishing any article paragraph or picture suggesting that military operations against Turkey are in a any sense a Holy War, a modern Crusade, or have anything whatever to do with religious questions. The British Empire is said to contain a hundred million Mohammedan subjects of the King and it is obviously mischievous to suggest that our quarrel with Turkey is one between Christianity and Islam. ${ }^{82}$

Within days, the satirical magazine Punch issued a dissident caricature entitled 'The Last Crusade', showing Richard Coeur de Lion overlooking Jerusalem suspiring 'My dream comes true'. A similar tension marked the official propaganda too. While allusions to the crusades were downplayed in Palestine they were exploited for a Christian audience in Britain. Yet, while the conquest of Palestine was packaged as a Christian endeavour domestically, the Holy Sites were portrayed to have been liberated not so much from Muslim presence as from the German Kaiser. ${ }^{83}$

The contested nature of all Holy Sites in Jerusalem, and the Kaiser's self-fashioning as a crusader during his Oriental Visit in 1898, were further reasons not to emphasize the crusader theme through restoration or labelling. Considerable efforts were made to erase the Kaiser's presence - for instance by bringing the bronze wreath Wilhelm II put on Saladin's tomb in Damascus to the Imperial War Museum in London, ${ }^{84}$ or by removing commemorative plaques. The original sites, however, were approached with more caution. C.R. Ashbee, as town planner, transformed and restored Jerusalem right, left and centre after

\footnotetext{
${ }^{80}$ Stucky, 'Henri Seyric'. On a much larger scale, the clearing of local inhabitants from these sites relate of course also to the much more coercive removal of Native Americans from US National Parks.

${ }^{81}$ Simon Goldhill, 'The Cotswolds in Jerusalem: Restoration and Empire', in Swenson, Mandler (eds.), From Plunder to Preservation.

${ }^{82}$ qu. in Eitan Bar-Yosef, 'The Last Crusade? British Propaganda and the Palestine Campaign, 1917-18', Journal of Contemporary History, xxvi (2001).

83 Ibid.

${ }^{84}$ Siberry, 'Images of the Crusades', 368.
} 
he was brought there by the first military commander Sir Ronald Storrs, but no attempts were undertaken to emphasise the changes made to the Al-Aqsa Mosque during the Crusades. Crusader-period doorways from the Church of the Holy Sepulchre were taken down for restoration but never put back because of the different owners' quarrels over the

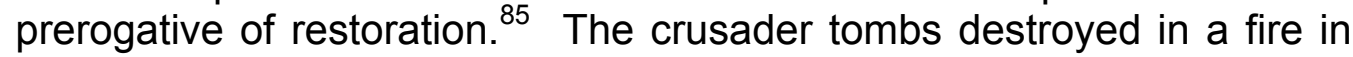
the nineteenth century were likewise never to be restored. While some sites built during the crusades were researched, excavated and restored as part of larger preservation policies, the restorations were not particularly promoted as a reclaiming of the crusades. ${ }^{86}$ Although there was no attempt to stake claims through the ostentatious restoration of crusader sites, allusions to the crusades were rarely far from the surface and returned in many guises. According to Country Life, the British High Commissioner's Residence, and the Palestine Archaeological Museum in Jerusalem, for instance, much resembled a 'Crusader Castle of Today'. ${ }^{87}$

\section{The crusades, heritage and empire}

What broader questions are raised by these four snapshots for understanding the refashioning of the crusades and the making of heritage in the imperial period more generally? First of all, across all sites and empires, a number of overarching trends can be observed. An initial phase, starting with the Napoleonic Egyptian Campaign and enhanced by the 'defence' of the Holy Sites during the Crimean War, saw a growing interest in crusader architecture everywhere in Europe. It was intertwined with debates about the origins of Gothic art. Scholars pondered whether the Gothic was engendered though the European encounter with Arab pointed arches during the crusades, or whether Arab art was derivative of European architecture. ${ }^{88}$ With the colonisation of the Mediterranean-the second phase-came a greater focus on preservation. Since the 1870 s, preservation was seen increasingly as a marker of civilisation, not just in the geographical context discussed here but also more broadly across Europe and the different Empires. Given the increased competition between colonial powers, which was apparent in the constant references to each other's failures and achievements, all states saw it as necessary to preserve the monuments of the past to establish themselves as civilised ruling powers. Yet the establishment of policies (rather than piecemeal repairs) was much slower on the Mediterranean islands than in other parts of the empires, especially in India, Egypt and Algeria. It was only during a third phase, started by the Italian restorations in Rhodes and brought to fruition by French

\footnotetext{
85 See Raymond Cohen, Saving the Holy Sepulchre: How Rival Christians Came Together to Rescue their Holiest Shrine (Oxford, 2008).

${ }^{86}$ Simon Goldhill, Jerusalem: City of Longing (Cambridge, MA, 2008) and personal communication.

${ }^{87}$ R. Fuchs and G. Herbert, 'Representing Mandatory Palestine', Architectural History xliii (2000).

88 Nabila Oulebsir, Les Usages du patrimoine: Monuments, Musées et politique coloniale en Algérie, 1830-1930 (Paris, 2004), 145.
} 
restorations in Syria, that interest in crusader sites surged, with a mutually enhancing effect on restorations across the region in all empires in the 1930s. It was at this moment too that the 'crusader sites' and their preservation were increasingly integrated into the culture of metropolitan heritage through colonial exhibitions and museum displays, i.e. that conscious attempts were made to 'bring' the empire 'home' to use Catherine Hall's phrase.

There was an overarching trend to think of the crusades in national terms, and to efface older interpretations. In contrast to the Early Modern period, where the crusaders were seen as a panEuropean, Christian enterprise, distinct national claims were made from the 1830s onwards. Individual crusaders became important heroes in various nation-building projects, made visible through new monumental displays such as the history paintings in Versailles or the statue of Richard I in Westminster. ${ }^{89}$ At the same time, the crusades became a template for modern imperialism. This was most noticeable in French imperial discourse. As early as the 1830s, the French historian JosephFrancois Michaud started to identify Charles X's Algerian campaign with a fulfilment of the crusades. ${ }^{90}$ Subsequently, the crusader period was used to provide the French empire with a longue durée and to claim continuity with 'the unique ability of the Franks to maintain a warm and fair relationship with their subjects'. ${ }^{91}$ Less strongly, perhaps, the colonialist approach to the crusades could also be found among representatives of other nations and was applied in other regions of Europe's empires. British writers such as Claude Reigner Conder compared British rule in India to Crusader rule in positive terms. ${ }^{92}$ These national-colonial narratives left little room for stylising the crusades and their sites as a European or a Christian heritage. A rare moment of an almost common European reclaiming occurred during the ceremonial entrance of the Allies into Jerusalem in 1917, but it was a crusade against the Kaiser that was invoked rather than a war against Islam. ${ }^{93}$

More striking than the nationalisation of the crusader sites is perhaps the relative absence of anti-Muslim rhetoric. British and French preservationists certainly often complained about the danger posed to monuments by local inhabitants, but these laments were little different from their statements about ignorant locals and philistine contemporaries in France or Britain. The French or British usually portrayed each other as worse vandals than the Ottomans, Arabs, Greeks and Maltese. How, then, did different imperialists deal with the fact that the complicated histories of appropriations and encounters were inscribed in the textures of the monuments themselves? Or, in

\footnotetext{
${ }^{89}$ Ellenblum, Crusader Castles, 18-39.

90 lbid, 18-23.

91 lbid, 45; The continuity is most explicitly stressed in Exposition coloniale internationale de Paris 1931, Commissariat General, Les Colonies et la vie française pendant huit siècles (Paris, 1933).

${ }_{92}$ Ellenblum, Crusader Castles, 47. The crusader theme also helped to foster German informal imperialism under Wilhelm II and became important for ideas about German Lebensraum in the European East.

${ }^{93}$ Bar-Yosef, 'The Last Crusade?'
} 
other words, what do the restorations say about ideas of hybridity? Here again, it seems that more attention was paid to removing the traces of other European histories than of Arab or Ottoman additions, which were sometimes expunged but were also often left in place. Reasons for this varied. As some (especially French and Italian) scholars viewed Arab architecture as derivate of Gothic art, it did not stand in the way of seeing building as national in origin. Other preservationists did not like the later additions, but kept everything in place out of Ruskinian principles. On some occasions, however, later additions were also celebrated as symbols of an ancient and ongoing encounter between cultures, ${ }^{94}$ almost eradicating the idea that both the crusades and modern colonialism were built on war and conflict. For instance, following the restoration of the cathedral-mosque of Famagusta, conducted in collaboration between the Curator of Ancient Monuments and the Evcaf, Jeffery wrote:

The new minaret at Famagusta may perhaps be regarded as onemore (sic) link in that series of monuments which recalls the amicable relations between Christians and Moslems before and during the earlier Crusades - Charlemagne and his friend Haroun er Rashid, Frederick II in the Mosque of Omar, not forgetting the romance of Coeur de Lion and Salah e'Din, or the fact that in the Holy City of Jerusalem most of the more important shrines are still common to both religions as they have been ever since the era of the Hegira! ${ }^{95}$

By looking deeper into the administrative archives on restoration work across several local contexts, rather than at the public portrayal of restoration, we find that the degree of intervention was heavily dependent on the importance given to maintaining good relations with either local or global Muslim populations for broader imperial policies. This rationale was at its most explicit in the absence of crusader rhetoric in Jerusalem, but it was not limited to the city. The Italians, for instance, treated Ottoman architecture with more care in Tripoli than in Rhodes. ${ }^{96}$ Hence, while the local meaning of certain sites was often erased in the national and colonial discourses addressed to metropolitan audiences, they were taken into account much more on the ground. Despite the similarities in national reinterpretations of the crusades and the increasing entanglement of preservation policies within and across empires, there were thus considerable differences with regard to the actual treatment of individual sites in different local contexts.

\footnotetext{
94 Exposition coloniale internationale de Paris 1931, Commissariat General, Les Colonies et la vie française pendant huit siècles (Paris, 1933)

${ }^{95}$ Report by Geroge Jeffery on 'Famagusta, Cyprus, The Great Mosque, 1934, CSA, SAI/992/34.

${ }^{96}$ On Tripoli and Rhodes se Mia Fuller, Moderns Abroad, chapters 1-3. A notable absence of German interest in crusader sites in the interwar period can perhaps also be explained by a wish not to endanger Germany's position in the region. On the decline of interest in crusader sites see Hans Eberhard Mayer, Bibliographie zur Geschichte der Kreuzzuege (Hannover, 1960).
} 
What then, of differences between the imperial powers? For France, the supposed Frenchness of all the crusader remains led to more statesponsored efforts to show the influence of France's art in foreign lands as a means of legitimising French colonial presence. A similar logic underpinned Italian rhetoric and drove restorations during the Fascist period (and arguably the German restoration of the castles of the Teutonic Order in East Prussia as well). By contrast, the link between restoration and national appropriation of the crusades appears much weaker in British policies. Where there was preservation at all, it was not so much focused on 'English' crusader monuments but encompassed all kinds of monuments.

There could be several reasons for these differences. A first is aesthetic. Whereas the French heritage institutions involved in the restorations were still influenced by Viollet-le-Duc, who emphasised restoration and purity of style, many of the English preservationists were influenced by Ruskinian appreciation of 'the value of age' and the respect of different periods. A second could be more instrumental. While the argument of a 'return' of 'previously colonised' territories served French and Italian colonial ambitions in the Mediterranean (and German expansion in Eastern Europe), it was of little use to the British. The French and Italians of course used the same logic about reclaiming the territories of the Roman Empire. None of this served a purpose in the British Empire. The only major overlap between the Roman and the British Empires was England, ${ }^{97}$ and Richard Coeur de Lion had sold off Cyprus and failed to conquer Jerusalem. For the Empire as a whole, and especially for the Jewel in its Crown, a discourse about guardianship, based on the respect of all monuments or all religions, which supposedly differentiated British from indigenous rule, was more potent as a tool of indirect rule than the reclaiming of national sites. ${ }^{98}$ It could be argued that the principles developed in India were then translated to other colonial contexts.

Can we therefore postulate a fundamental difference between British and other imperial preservation policies? In some ways, a better understanding of different areas of European empires is necessary to answer this question. Judging from the comparisons now available it appears that the treatment of the crusader sites is only partially representative of imperial heritage politics more generally. The picture gets more complicated when we broaden our view. Not all of French colonialism was built on national 'reclaiming'. Although the money spent on the Crac in Syria was exceptional, most projects by the Antiquities Service in Syria focussed on other periods. In the Far East, the civilising nature of preservation was also much more heavily emphasized. Likewise, not all British preservation policies were based on a universal understanding of heritage. In particular, if we shift our gaze from government-driven policies and the action of elite groups like the SPAB to more popular religious and archaeological movements, reclaiming of

\footnotetext{
97 Mary Beard, 'Officer and Gentlemen, Roman Britain and the British Empire', in Swenson, Mandler (eds.), From Plunder to Preservation, 49-61.

${ }^{98}$ See Swenson, 'Heritage of Empire', 12-14.
} 
heritage (and territories) because they 'are ours' and always 'were ours' can be found. The broad popular interest in Egypt, for example, was largely based on the idea that Egypt was British because it was the cradle of biblical civilisation that had found its direct descendents in protestant Britain. ${ }^{99}$ In some ways it was unnecessary to invoke the crusades in Jerusalem, as British claims to the Holy City were much more widely underpinned by the Archbishop of York's idea that 'Palestine is ours' as a biblical heritage.

Generalising statements about whether preservation was primarily underpinned by ideas of localism, nationalism or universalism get even blurrier if we look at the actions of some of the heritage-makers that we observed caring for crusader heritages in other contexts. While we only saw fierce competition between European powers when it came to restoration or reclaiming, the same individuals co-operated across borders to save 'monuments of universal interest' in Europe and collaborated on rescuing Arab or Ottoman antiquities in Egypt or Turkey. $^{100}$ Although this language of universal heritage was hardly mobilised for the 'crusader sites', there was nevertheless much collaboration and even friendship between scholars and preservationists of different nationalities. The different colonial governments also aided scholarly relations. 'A very good friendship owing to the similarities of our tastes', for instance, connected Jeffery and Enlart after the High Commissioner of Cyprus had first asked Jeffery to assist Enlart with his work in Cyprus, fostered through common work setting up the lapidary museum in Nicosia, and visits and correspondences over the years until Enlart's death. ${ }^{101}$ Here, as in other areas of preservation and scholarship, fierce international competition was accompanied by strong international collaboration. ${ }^{102}$ Preservationists often tactically used foreign 'superiority' to convince people in their own governments unwilling to provide the necessary funding and infrastructure for preservation. There might even be some evidence that complaints in the foreign press about national neglect were deliberately created in order to provide material to cite. ${ }^{103}$

The history of the preservation of crusader sites thus enriches what we know about the national and colonial appropriation of the crusades from historiographic sources, revealing that uses on the ground were often different from the narratives created for domestic audiences. This

\footnotetext{
99 See David Gange and Michael Ledger-Lomas (eds.), Cities of God: Archaeology and the Bible in nineteenth century Britain (Cambridge, 2013); David Gange, 'Unholy Water: Archaeology, the Bible, and the First Aswan Dam', in Swenson, Mandler (eds.), From Plunder to Preservation.

100 SPAB Archives, 'Egypt' and 'Ottoman Antiquities'; Swenson, The Rise of Heritage, ch. 5; Donald Malcom Reid, Whose Pharaohs? Archaeology, Museums and Egyptian National Identity from Napoleon to World War I (Berkely, CA, 2002).

${ }^{101}$ George Jeffery, 'Autobiographical Notes' (1920), in Pilides (ed) George Jeffery, I, 83; George Jeffery to Secretary of the SPAB, 24 June 1901, in ibid, II, 596-7. On government assistance to French Scholars, AN, F17/2960, Mission de Camille Enlart en Chypre; Heiniker-Heaton (C.S.) to Consul of France, 25 Jan. 1933, CSA, SAI 431/33.

${ }^{102}$ For other examples see Swenson, Rise of Heritage.

${ }^{103}$ Pilides, George Jeffery, I, p. 20-21.
} 
also helps us understand more general mechanisms in the history of heritage. The examples discussed here show how much the preservation of each individual site was intertwined with the preservation of other sites across national and imperial boundaries. They also draw attention to the dense personal connections that underpinned these entanglements. At the same time, the history of the crusader sites emphasizes the importance of local context to understand how coexisting and often contradictory notions of heritage were formulated and used. Their history is a case in point for seeing how the nationalisation of heritage involves not just the construction of a national heritage but also the effacing of other legacies both above and below the scale of the nation. Yet these erasures were never total or absolute. Personal records and archives of the different colonial bureaucracies reveal that interpretative frameworks were much less consistent than the confident tone of many publications or exhibitions would have us believe. There was rarely a straight progression or replacement of interpretations. Rather, the case studies reveal that a multiplicity of meanings continued to exist for different (and sometimes the same) actors.

In his study on crusader castles and modern histories, Ronnie Ellenblum concluded that modern categories such as 'colonialism' are often unhelpful for understanding the complex interactions in the period of the crusades themselves. Paradoxically, the same can be said for the very period that engendered these categories. The preservation of 'crusader sites' was certainly driven by national and colonial agendas, and it is necessary to understand these agendas. However, these were only some of the complex motives and affective relations which should be unearthed if we want to gain a better understanding of what drove the making of heritage in the modern world. 


\section{Illustrations}

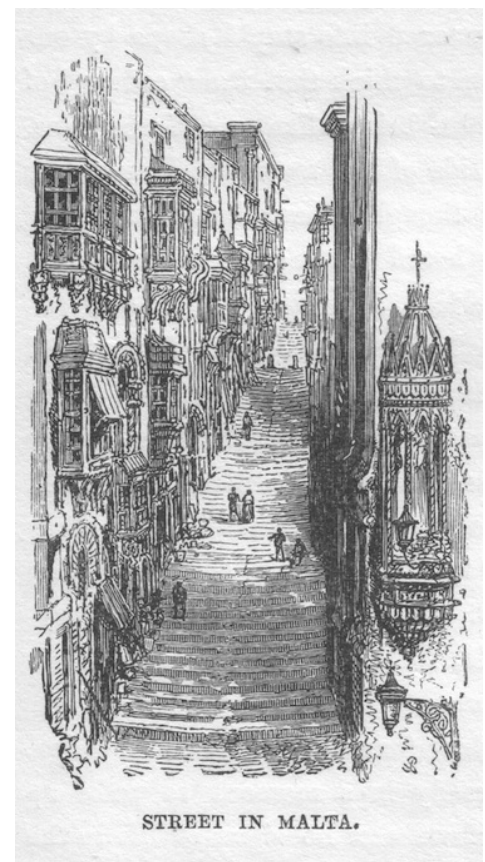

1. Street in Malta from Half Hours in the Holy Land. Travels in Egypt, Palestine, Syria (London, 1898), 14 (author's collection).

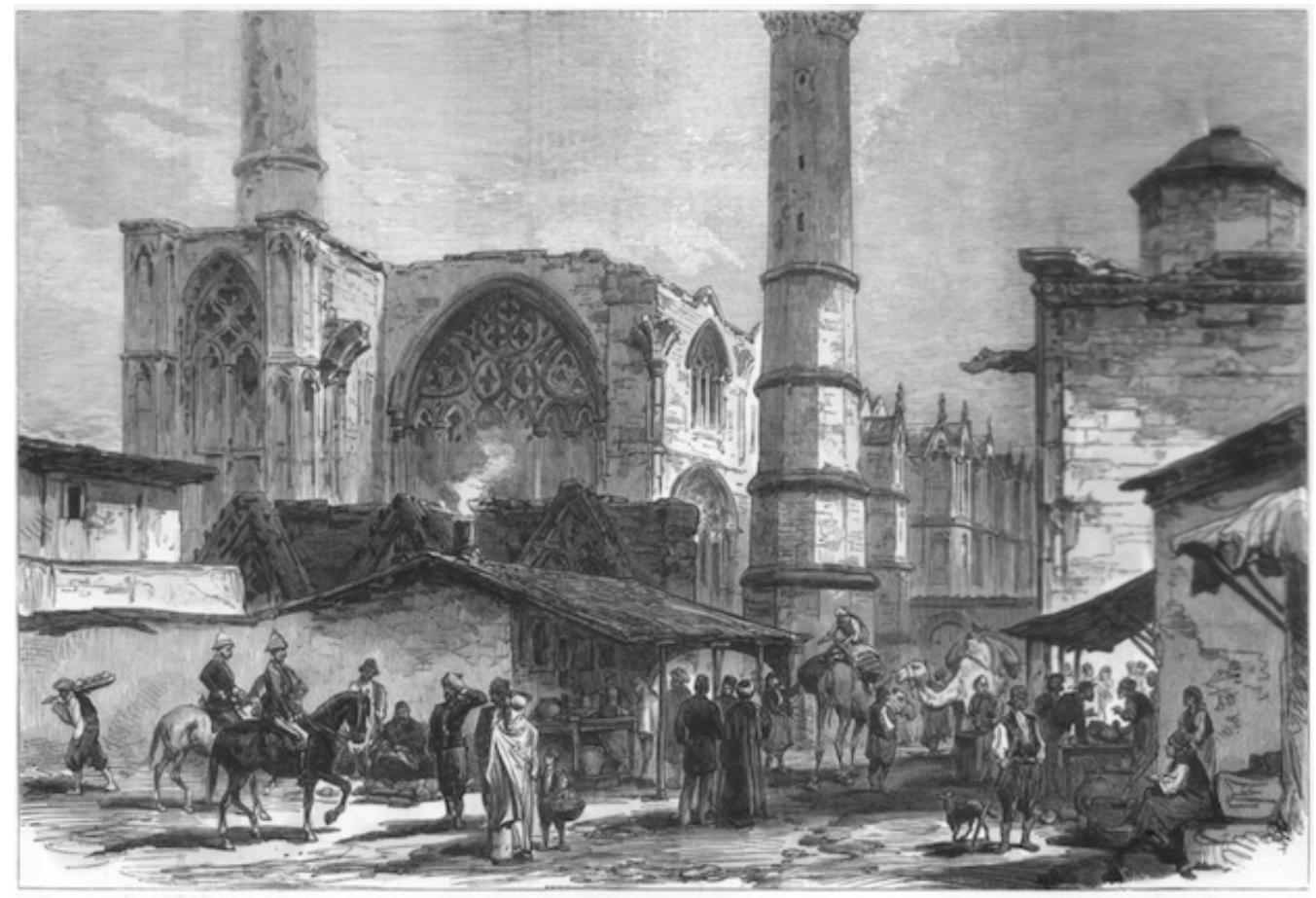

BKETCHES OF CYPRU, BY OUR BFBCTAL ARTIBT: BT. BOPHIA, NICOSTA,

2. St. Sophia, Nicosia from The Illustrated London News, 7 Sept. 1878 , which celebrated the acquisition of Cyprus through a series of special illustrations (author's collection). 


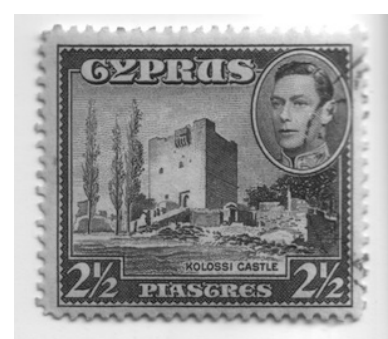

3. Stamp of Cyprus showing Kolossi Castle and King George VI, c. 1938 (author's collection).

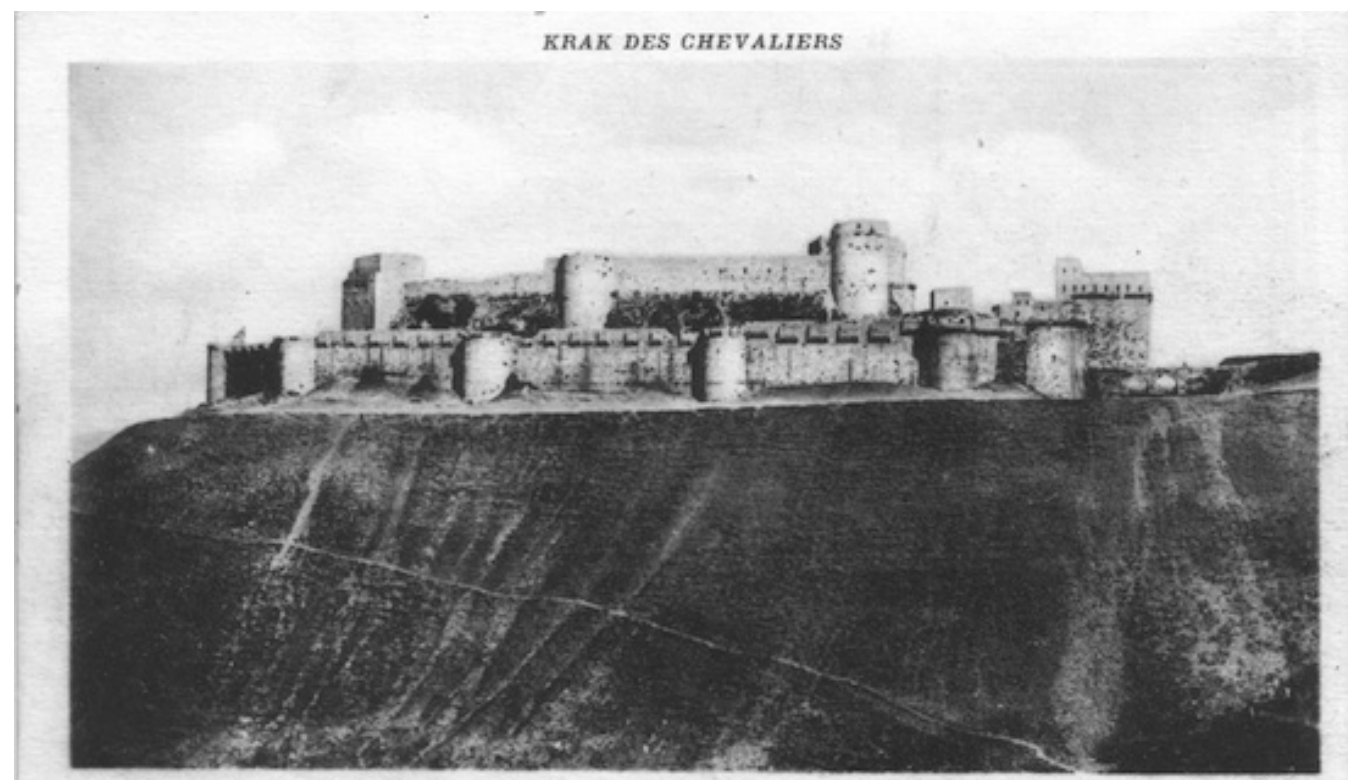

2. Au moment des Croisades, nos aĩeux ont occupé le pays Alaouĩte, Il y subsiste des ruines imposantes de leurs forteresses. L'un des chateaux forts les mienx conservés est Qalaat el Hosn : le Krak des Chevaliers.

4. Krak des Chevaliers. French postcard from the mandatory period with the caption 'During the Crusades, our ancestors occupied the Alawite land. Impressive ruins of their fortresses still exist. One of the best-preserved castles is the Qalaat el Hosn: the Krak des Chevaliers' (author's collection). 